\title{
Client Selectivity Among Mid-Sized Auditing Firms: Evidence From The Post-Sox Audit Market Realignment
}

Charles P. Cullinan, Bryant University, USA

Hui Du, University of Houston-Clear Lake, USA

\begin{abstract}
Considerable realignment in the audit market occurred in the wake of the Sarbanes-Oxley Act of 2002, with many clients switching from a Big 4 to a non-Big 4 auditor. We examine a sample of 212 former Big 4 clients who switched to either a mid-sized auditing firm (i.e., BDO Siedman, Crowe Horwath, Grant Thornton and McGladrey) or a small auditing firm. We consider reasons why clients may prefer a mid-sized firm rather than a small firm (called "client demand" characteristics) and reasons why auditors may be willing to accept an audit engagement (called "auditor supply" characteristics). Among client demand characteristics, we find that clients are more likely to engage a mid-sized auditing firm when the client is larger, has higher asset turnover, and has foreign operations. From an auditor supply perspective, we find that a midsized auditing firm is more likely to accept the client if the client is willing to pay higher audit fees and uses the auditor for non-audit services.
\end{abstract}

Higher financial leverage could be seen from either a client demand or auditor supply perspective. From a client demand perspective, higher financial leverage would make clients prefer mid-sized auditors, as these clients' needs for financing could lead them to seek a more "brand-name" auditor to enhance their credibility with banks and other creditors. From an auditor supply perspective, auditors may prefer to avoid clients with higher leverage, which reflects financial riskiness. These financially risky clients may result in adverse reputational and/or legal costs for the auditing firm. We find that clients with higher leverage are less likely to engage a mid-sized CPA firm. These results suggest that mid-sized auditors are somewhat selective in the clients they are willing to accept.

Keywords: Auditor Change; Mid-sized Auditing Firms; Sarbanes-Oxley; Client-demand; Auditor-supply

\section{INTRODUCTION}

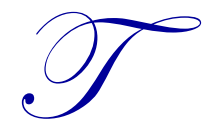

he audit market for smaller publicly-traded companies was materially altered in the wake of the Sarbanes-Oxley Act and the requirement for auditing firms to issue an opinion on their client's internal control report. As a result of these changes, there has been a considerable realignment in the audit market, especially among smaller clients who have become less likely to have a Big 4 accounting firm as their auditor. ${ }^{1}$ For example, the GAO (2008) reports that non-Big 4 accounting firms materially increased their market share among companies with less than $\$ 1$ billion in total revenue. Those clients choosing to move away from Big 4 auditors had to select new auditors from non-Big 4 auditing firms. Within the non-Big 4 firms, the GAO distinguished mid-sized auditing firms (i.e., BDO Siedman, Crowe Horwath, Grant Thornton and McGladrey) from small auditing firms. Recent research suggests that the market perceives differences between the mid-sized and small tiers of non-Big 4 firms (i.e., Cullinan et al., 2011) and that there may be audit quality differentiation between

\footnotetext{
${ }^{1}$ Much of the post-SOX decrease in the Big 4's smaller clients may be the result of smaller clients dismissing Big 4 auditor as a results of fee increases, rather than Big 4 auditors resigning from their smaller clients (Ettredge et al . 2007a).
} 
types of mid-sized and small auditing firm (Fuerman and Kraten, 2009). The GAO (2008) report also indicates that the mid-sized firms have increased their client base and market share among publicly-traded clients. This increased client base may allow these mid-sized firms to be more selective in their choice of clients.

Given the emerging prominence of the mid-sized auditing firms, the objective of this paper is to assess client selectivity among mid-sized auditing firms by examining auditor-client realignment among former Big 4 clients in the post-SOX era. Specifically, we examine whether former Big 4 clients select mid-sized successor auditors or realign with non-Big 4, non-mid-sized (i.e., small) auditing firms. Figure 1 presents the types of auditclient realignment we examine in graphical form.

Former Auditor $\quad$ Successor Auditor

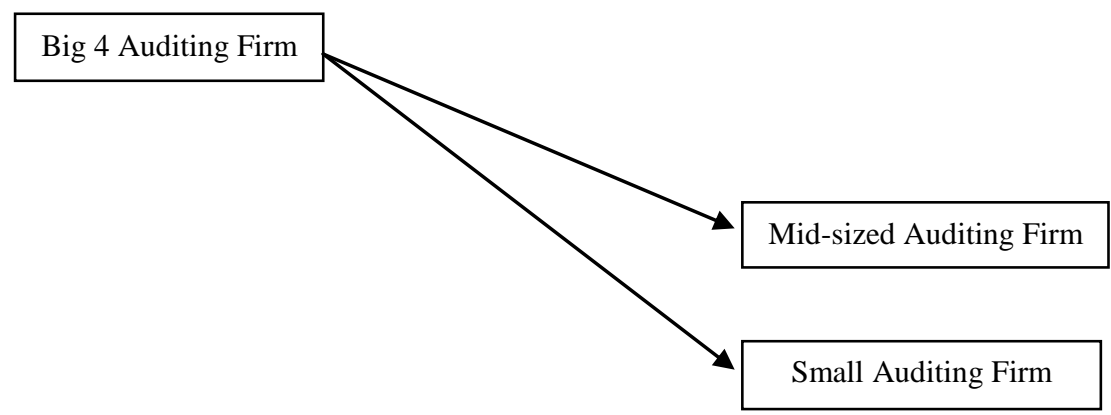

Figure 1: Auditor-Client Realignments Examined

We classify the characteristics of former Big 4 clients switching auditors into categories of client-demand characteristics and auditor-supply characteristics. The client-demand characteristics include client size, asset turnover, foreign operations, and leverage. The audit-supply characteristics include clients having internal control weaknesses and those receiving going concern opinion, whether the previous auditor resigned, audit fees, non-audit service fees, and audit busy season. From a client-demand perspective, clients perceive the enhanced capacity and credibility of the mid-sized auditing firms in the post-SOX era and thus may prefer to select mid-sized auditing firms when looking for a new auditor. From an auditor-supply perspective, the mid-sized firms have more clients requesting their services, and the increased demand for their services has the potential to make the mid-sized auditing firms more selective in their choice of clientele. Hogan and Martin (2009) provide mixed evidence on midsized firm client selectivity. They find that mid-sized firms are accepting clients with increased risks switching from Big 4 predecessor auditors while they are also shedding clients with higher risks from their existing client base. We contribute to this literature by focusing on clients who are switching from a Big 4 firm to a mid-sized firm or who "skip a tier" and go directly from a Big 4 to a small auditing firm.

Using a sample of 212 auditor changes from 2003 to 2008 in which the former auditor was a member of Big 4 and the successor auditor was a mid-sized or a small auditing firm, we find both client-demand characteristics and auditor-supply characteristics are associated with auditor-client realignment during this period. From a clientdemand perspective, larger clients with higher asset turnover (i.e., sales/assets) were more likely to align with midsized firms as these clients seek the richer resources that a mid-sized auditing firm could offer. Clients with a foreign operation are also more likely to choose a mid-sized firm, which is more likely than a small firm to have international capacity.

From an auditor-supply perspective, mid-sized auditing firms are more likely to align with clients who are willing to pay higher audit fees and who are willing to purchase non-audit services. We do not find evidence of midsized auditing firms avoiding clients with problems such as internal control weaknesses, going concern opinions or auditor resignation. We do find that mid-sized auditors are less likely to associate with clients with higher financial leverage. However, the results of characteristics of auditor-supply are mixed: mid-sized auditing firms do not align 
with higher leverage clients but generally do not mind having clients with issues of internal control, going concern, and auditor resign.

Our study contributes to the literature in two ways. First, by studying auditor changes in the wake of the passage and implementation of the Sarbanes-Oxley Act, we examine the extent to which the mid-sized auditing firms may have been selective in their choice of clients in light of their increasing market share. Second, we examine auditor realignments in which the non-Big 4 successor auditors are separated into mid-sized and small auditing firms. Consistent with other recent research (i.e., Lawrence, et al., 2011), we address both client-demand effects and auditor-supply effects to develop and test a model of auditor-client realignments among former Big 4 clients.

The remainder of this paper is organized as follows. First, we review the literature addressing auditor-client alignment and discuss mid-sized auditing firms. We then develop a model of auditor-client realignments for former Big 4 clients. Next we discuss the research method used to empirically test the auditor-client realignment model. The results of our testing are then presented. The paper concludes with a summary and the implications of our findings.

\section{LITERATURE REVIEW}

In this section of the paper, we first review the extant research related to auditor-client alignments. We then address research examining non-Big 4 auditing firms, especially those studies dealing with differences between midsized and small auditing firms.

\section{Auditor-Client Alignment}

Research examining why clients are associated with certain types of auditors (i.e., auditor-client alignment) has been conducted for a number of decades. For an auditor-client relationship to occur, the client must chose to associate with the auditor and the auditor must chose to associate with the client (Dey, 2010). We will refer to possible reasons for clients to prefer certain types of auditing firms as "client-demand" factors. Possible reasons for auditors to prefer (or to avoid) certain types of clients will be referred to as "auditor-supply" factors.

Studies examining client-demand factors are generally premised on the idea that certain types of clients will seek to align themselves with a Big 4 auditor as a result of the perceived credibility and capabilities of Big 4 accounting firms. These studies have been performed on Initial Public Offerings (IPOs) in New Zealand (Firth and Smith, 1992) and Quebec (Bédard et al., 2000), cross-sectionally in Brazil (de Mello-e-Sourza, 2004), Finland (Knechell et al., 2008), and the United States (e.g., Chaney et al., 2004; Dey, 2010), and based on US auditor changes (e.g., Tate, 2007; Landsman, 2009).

Two of the most consistent results in this literature are that larger clients and clients with higher levels of debt prefer to be associated with a Big 4 firm (e.g. Broye and Weill, 2008). Larger clients prefer Big 4 firms due to the Big 4 firms' capabilities and availability of resources to service these larger clients. The findings that clients with more debt (typically measured by leverage) are more likely to be associated with Big 4 auditing firms is attributed to the idea that Big 4 firms may enhance the credibility of the financial statements, leading to a lower costs of capital. Broye and Weill (2008) suggest that the association between debt and Big 4 auditing firms is particularly important in countries (such as the US) with higher litigation risk. Asset turnover has also been examined by some studies and has been found to be associated with a greater likelihood of having a Big 4 auditing firm (e.g., de Mello-e-Sourza, 2004; Chaney et al., 2004).

In addition to factors making clients prefer Big 4 auditors (client-demand factors), more recent research has also considered factors associated with whether Big 4 auditors would prefer certain types of clients (i.e., auditorsupply factors). For example, Hogan and Martin (2009) found that both Big 4 and mid-sized auditing firms were shedding clients with higher risk profiles. Similarly, Lawrence et al. (2011) found that perceived Big 4 quality differences may actually result from Big 4 auditors choosing to reject lower quality clients rather than from differences in the actual services provided by Big 4 firms. 


\section{Mid-sized Auditing Firms}

\section{Market Share and Implications}

The GAO (2008) found that the Big 4 auditing firms have ceded market share among smaller publiclytraded firms from 2002 to 2006 while mid-sized auditing firms have gained market share during this period. For example, among publicly-traded clients with between $\$ 100$ million and $\$ 500$ million of revenue, the market share of the Big 4 firms decreased from $90 \%$ to $71 \%$, while the market share of mid-sized firms increased from $6 \%$ to $16 \%$ of these clients. Among publicly-traded firms with between $\$ 500$ million and $\$ 1$ billion of revenue, the market share of the mid-sized auditing firms increased from $2 \%$ to $6 \%$ of this market.

The effects of these changing market shares on the competitive position of mid-sized auditing firms indicate that these firms may have the ability to be more selective in their choice of clientele. For example, Hogan and Martin (2009) document that mid-sized firms are shedding some of their existing higher risk clients while accepting many clients who were former Big 4 clients. Cullinan and Du (2010) also find that the percentage of former clients from which the mid-sized auditing firms resigned (as opposed to being dismissed by the client) was higher than either the Big 4 firms or small auditing firms. Overall, these findings support the notion that mid-sized auditing firms have the ability to be more selective in their client acceptance decisions than small auditing firms.

\section{Quality of Audit Service Differentiation}

There is an emerging body of literature examining various measures of audit quality and perceived audit quality among the Big 4, mid-sized and small auditing firms. This issue is of potential importance because Big 4 firms have historically differentiated themselves from other firms by the perception that they provide audits of higher quality. If the mid-sized firms were perceived to be of lower quality, their ability to take advantage of the post-SOX realignment in the audit market would be limited.

Francis et al. (1999) examined discretionary accruals, which were viewed as a measure of the auditor's effectiveness in constraining opportunistic behavior by management. Francis et al. (1999) found that clients of midsized firms had lower discretionary accruals than small firms.

Using the propensity of an auditor to issue going concern audit opinions as the measure of audit quality, Gieger and Rama (2006) found no difference in audit quality between mid-sized and small auditing firms, while Boone et al. (2010) found weak evidence that the Big 4 have a higher tendency to issue going concern opinions than the mid-sized firms.

Initial public offering (IPO) underpricing has also been used as a measure of audit quality. Both Beatty (1989) and Albring (2007) found less underpricing (which they equate with higher quality auditing) among the clients of mid-sized auditing firms as compared to clients of small auditing firms. Using litigation against auditing firms as a measure of audit quality, Fuerman and Kraten (2009) found that mid-sized auditing firms were less likely to be involved in auditor-malpractice litigation than small auditing firms. Krishnan (2008) finds that mid-sized auditors have become more conservative in the post-SOX period.

The stock market reaction to auditor-client realignments among the Big 4, mid-sized and small firms has also been studied. Using a Big 4/non-Big4 dichotomy, Chan et al. (2011) find that the market does not react negatively when a client switches from a Big 4 to a non-Big 4 firm when the main reason for the change is a reduction in audit fees. Using three levels of CPA firms, Cullinan et al. (2011) found that the market reacted negatively to a move from a Big 4 to a small auditing firm. When clients realigned with mid-sized auditing firms, however, the market reaction does not differ if the successor auditor was a Big 4 or mid-sized firm. These results indicate that the stock market views Big 4 and mid-sized firms to be of similar quality.

Overall, the results of these studies suggest that mid-sized firms may have achieved some audit quality differentiation relative to small auditing firms. The research is also consistent with a three-tier audit market structure, with Big 4, mid-sized firms, and small firms having different levels of credibility in the audit marketplace. 


\section{A MODEL OF AUDITOR-CLIENT REALIGNMENT FROM BIG 4 TO MID-SIZED OR SMALL AUDITING FIRMS}

In this section of the paper, we propose a model to explain auditor-client realignment when a client changes from a Big 4 to either a mid-sized or a small firm. Our model discusses both reasons for clients to prefer certain types of auditors (client-demand factors) and reasons for auditors to prefer certain types of clients (auditor-supply factors). Note that some factors may represent both client-demand preferences and auditor-supply preferences, and thus the distinction between these factors is not absolute.

\section{Client-demand Factors}

One of the most consistent results in the auditor choice literature is that larger clients prefer larger auditing firms (e.g., Landsman, 2009; Knechel, 2008). Similarly, clients with higher asset turnover (i.e., sales/assets) tend to have larger auditing firms (e.g., de-Mello e Sourza, 2004). The rationale for this relationship is that larger clients need the greater resources available from the larger auditing firms and that auditing firms lacking staff and other resources are unable to perform the audit of larger companies on a timely basis. We expect that larger clients with higher asset turnover will be likely to prefer a mid-sized, rather than small auditing firm.

Clients with foreign operations have also been found to prefer larger auditing firms (e.g., Bédard et al., 2000). Clients having foreign operations prefer auditing firms with a global presence to ensure that the auditing firm provides international capacity with local knowledge in foreign countries. We expect that clients with foreign operations would prefer mid-sized firms, which have international operations or corresponding firms in foreign countries to assist them in completing the audits of firms with foreign operations.

Research has also found that clients with greater financial leverage are more likely to be associated with larger auditing firms (Chaney, 2004; Hay and Davis, 2002). ${ }^{2}$ Firms with higher degrees of financial leverage are posited to prefer large auditors due to the perceived credibility of the financial statements of clients audited by these larger firms (especially the Big 4 auditing firms). The enhanced financial statement credibility may result in a lender being more willing to extend credit to a client of a large auditing firm and potentially at a more favorable interest rate. As discussed earlier, mid-sized auditing firms appear to have gained greater credibility in the financial markets (relative to small auditing firms), which could lead to clients with higher financial leverage preferring these midsized firms over small firms.

\section{Auditor-Supply Factors}

\section{Factors Making Potential Client More Desirable}

Larger clients with higher asset turnover typically generate higher fees than small clients. They are also often seen as more prestigious clients. Mid-sized auditing firms would thus be expected to be more likely to accept larger clients due to their fee generating abilities and their prestigious images.

Similarly, clients who are willing to purchase non-audit services ${ }^{3}$ from the auditing firm may be seen as more desirable clients and mid-sized auditing firms would be more likely to accept clients which are willing to engage the auditing firm for non-audit services as well. Less price-sensitive clients would also be more desirable clients due to their willingness to pay higher fees for audit services. ${ }^{4}$ We expect that auditors are more willing to accept clients that hire the firm for non-audit services and are willing to pay a higher audit fee (relative to company

\footnotetext{
${ }^{2}$ Broye and Weill (2008) find that this relationship varies depending on the litigiousness of the country involved. In the U.S., this relationship has been consistently found to exist.

${ }^{3}$ While the Sarbanes-Oxley Act restricted the ability of auditing firm to provide consulting services to their audit clients, auditing firms are still allowed to provide some non-audit services (such as tax services) to their audit clients.

${ }^{4}$ The ability of mid-sized firms to charge higher fees than small firms in recent periods has yielded mixed results. Basioudis and Francis (2007) finding fee premium for mid-sized firms relative to small firms, while Cullinan and Du (2010) found no differences in fees between the mid-sized and small firms. Research fairly consistently finds that mid-sized auditing firms charge lower fees than the Big 4 firms.
} 
size). Finally, mid-sized auditing firms may be more willing to take engagements that use their spare staff resources during the less-busy periods of the year (i.e., non-December/January fiscal year ends).

\section{Factors Making Potential Clients Less Desirable}

The recent increase in audit market share of mid-sized auditing firms may permit these firms to be more selective about their clients (Hogan and Martin, 2009). Problematic clients are more likely to be rejected by an auditor who can be selective in their choice of clientele. The problematic clients may include potential clients with material weaknesses in their internal control process. Similarly, clients from which the predecessor auditor resigned may be perceived to be less desirable clients, and thus less likely to be able to engage a mid-sized auditing firm. Therefore, we expect internal control weakness, going concern opinion, and auditor resignation to be negatively related to the likelihood of engaging a mid-sized auditing firm.

Clients with higher financial risk profiles may be seen as less desirable clients, and thus less likely to engage a larger auditing firm (Lawrence et al., 2011). Higher financial risk clients are more likely to fail, which could impose adverse reputational and/or legal liability effects on their auditing firm. As mid-sized auditing firms have gained market share, they may be less willing to accept financially riskier clients. We use two measures of financial risk in our study - whether the previous auditor issued a going concern opinion and the client's financial leverage (Ebrahim, 2010). Thus, we expect clients with going concern opinions and higher financial leverage to be less likely to engage a mid-sized auditing firm. Note that the financial leverage prediction is opposite to the predication from the client-demand perspective in which clients with higher financial leverage will be more likely to demand a mid-sized auditor. Which of these two effects is greater remains an empirical question to be answered by our study.

\section{RESEARCH METHODS}

We used the Audit Analytics database to identify changes in auditors of publicly-traded clients from 2003 to 2008. We then limited the sample to auditor changes in which a Big 4 auditor was the predecessor auditor and the successor auditor was not a Big 4 firm. We then matched the auditor change sample to the Compustat database, which yielded a total sample of 212 auditor changes. Mid-sized auditing firms were the successor auditors for 128 of the clients and small auditing firms were the successor auditors for 84 of the clients in our sample. A summary of the variables gathered and their measurements is presented in Table 1. Note that all of the variables, except nonaudit fees and audit fees/assets are measured during the period immediately preceding the auditor change.

Table 1: Variable Measurement and Source

\begin{tabular}{|c|c|c|}
\hline Variable & Measurement & Source \\
\hline Assets & Assets in dollars in year before auditor change & Audit Analytics \\
\hline Asset turnover & Sales/assets in year before auditor change & Audit Analytics \\
\hline Foreign operations (Yes/No) & $\begin{array}{l}1=\text { Client reports income from foreign operations } \\
0=\text { Client does not report income from foreign operations }\end{array}$ & Compustat \\
\hline Internal control issue & $\begin{array}{l}1=\text { Client reported internal control issue in year preceding auditor } \\
\text { change } \\
0=\text { No internal control issue reported }\end{array}$ & Audit Analytics \\
\hline Previous auditor resigned & $\begin{array}{l}1=\text { Previous auditor resigned from client } \\
0 \text { Previous auditor was dismissed by client }\end{array}$ & Audit Analytics \\
\hline Busy season year end & $\begin{array}{l}1=\text { Fiscal year end in December or January } \\
0=\text { Fiscal year end other than December or January }\end{array}$ & Audit Analytics \\
\hline Non audit fees? (Yes/No) & $\begin{array}{l}1=\text { Client purchased non-audit service from new auditor } \\
0=\text { Client did not purchase non-audit services from new auditor }\end{array}$ & Audit Analytics \\
\hline Audit fees/assets & Audit fees charged by new auditor/assets & Audit Analytics \\
\hline Going concern opinion & $\begin{array}{l}1=\text { Going concern opinion in year before auditor change } \\
0=\text { No going concern opinion }\end{array}$ & Audit Analytics \\
\hline Leverage & Financial Leverage (Debt/assets) & Compustat \\
\hline
\end{tabular}


For the first stage of our analysis, we computed the means for each of the variables identified in Table 1 for the two groups of interest - whether the successor auditor was a mid-sized auditing firm or a small auditing firm. We then used t-tests to determine whether the differences in means between the two groups were statistically significant. We then developed a logistic regression model. The dependent variable in the logistic model was a dichotomous variable indicating whether the successor auditor was a mid-sized auditing firm or a small auditing firm. The independent variables were the measures of client-demand and auditor-supply factors shown in Table 1.

\section{RESULTS}

\section{Univariate Results}

The results of our testing of the differences in means between the two types of successor auditor are presented in Table 2. As expected, larger clients with higher asset turnover (i.e., more sales relative to assets) are more likely to engage a mid-sized auditing firm. Similarly, clients with foreign operations are also more likely to select a mid-sized auditing firm.

There were no significant differences between the mid-sized auditing firm clients and small auditing firm clients in the variables measuring whether the client had an internal control issue, had a busy season fiscal year end, or whose previous auditor resigned. In our univariate testing, clients receiving a going concern opinion were less likely to engage a mid-sized auditing firm, while clients using their auditors for non-audit services were more likely to hire a mid-sized auditor. There were no significant differences in audit fees (as a percentage of assets) or financial leverage and the types of successor auditing firm. These results suggest that mid-sized firms prefer to avoid clients with higher financial risk, as measured by the presence of a going concern opinion ${ }^{5}$, and that clients generating higher fees were more likely to be accepted as clients by mid-sized auditing firms.

Table 2: Comparison of Former Big 4 Clients Who Switched to Mid-sized Firms or Small Firms

\begin{tabular}{|l|c|c|c|}
\hline \multicolumn{1}{|c|}{ Variable } & To mid-sized & To small firms & t $(\mathbf{p}>\mathbf{t})$ \\
\hline Assets & $\$ 453,000,000$ & $\$ 217,000,000$ & $-2.29(0.0231)$ \\
\hline Asset turnover & 1.070 & 0.835 & $-1.74(0.0830)$ \\
\hline Foreign operations (Yes/No) & $41.1 \%$ & $23.8 \%$ & $-2.67(0.0082)$ \\
\hline Internal control issue & $84.4 \%$ & $86.9 \%$ & $0.51(0.6121)$ \\
\hline Previous auditor resigned & $28.1 \%$ & $32.1 \%$ & $0.62(0.5335)$ \\
\hline Busy season year end & $73.4 \%$ & $76.2 \%$ & $0.45(0.6546)$ \\
\hline Non audit fees? (Yes/No) & $82.0 \%$ & $70.2 \%$ & $-2.02(0.0450)$ \\
\hline Audit fees/assets & 0.0076 & 0.0111 & $0.99(0.2429)$ \\
\hline Going concern opinion & $3.9 \%$ & $13.1 \%$ & $2.25(0.0262)$ \\
\hline Leverage & 0.4991 & 0.6718 & $1.44(0.1530)$ \\
\hline
\end{tabular}

Sample size:

Clients switching from Big 4 to mid-sized firms $\quad 128$

Clients switching from Big 4 to small firms $\quad \underline{84}$

Total sample size

$\underline{\underline{212}}$

\section{Logistic Regression Results}

The logistic regression results are presented in Table 3. The overall model chi-square is 41.8379 , which is significant at 0.0001 . The second column in the table displays whether the variable is designed to measure a clientdemand (CD) or auditor-supply factor. Note that some of the variables may be related to both factors.

\footnotetext{
${ }^{5}$ A going concern opinion could also be viewed as making the client less desirable because if the client were to fail, the auditor's ability generate future fees from the client would be reduced.
}

(C) 2012 The Clute Institute http://www.cluteinstitute.com/ 
Table 3: Logistic Regression Results

Dependent variable: Whether new audit firm was mid-sized or small firm

\begin{tabular}{|c|c|c|c|c|}
\hline Variable & $\begin{array}{l}\text { Client-demand (CD) or } \\
\text { Auditor-supply (AS) and } \\
\text { expected sign(s) }\end{array}$ & Estimate & chi-square & $\begin{array}{l}\text { p }>\text { chi } \\
\text { square }\end{array}$ \\
\hline Intercept & & -13.117 & 16.80 & 0.0001 \\
\hline log of Assets & CD \& AS (+) & 0.701 & 16.47 & 0.0001 \\
\hline Asset turnover & CD \& AS (+) & 0.690 & 8.74 & 0.0031 \\
\hline Foreign operations (Yes/No) & $\mathrm{CD}(+)$ & 0.725 & 4.60 & 0.0321 \\
\hline Internal control issue & AS (-) & -0.563 & 1.36 & 0.2432 \\
\hline Previous auditor resigned & AS (-) & -0.505 & 1.97 & 0.1601 \\
\hline Busy season year end & AS (-) & -0.034 & 0.01 & 0.9275 \\
\hline Non audit fees? (Yes/No) & AS (+) & 0.725 & 3.89 & 0.0486 \\
\hline Audit fees/assets & AS (+) & 42.059 & 6.48 & 0.0109 \\
\hline Going concern opinion & AS (-) & -0.626 & 0.87 & 0.3512 \\
\hline Leverage & $\mathrm{CD}(+), \mathrm{AS}(-)$ & -1.057 & 4.12 & 0.0423 \\
\hline
\end{tabular}

Model statistics:

chi-square $\quad 41.8379$

$\mathrm{p}>$ chi-square $\quad 0.0001$

McFadden Pseudo R 20.1469

Sample size 212

Examining the estimates, chi-square and p-values, the first two client-demand factors (assets and asset turnover) are both significant at conventional levels. These results suggest that larger clients, with higher sales (relative to size) are more likely to engage a mid-sized auditing firm as their successor auditor. Note that these two variables also reflect auditor-supply factors. While larger companies prefer mid-sized auditing firms, mid-sized auditing firms also appear to be more willing to accept larger clients, which are likely to generate higher overall audit fees. Clients with foreign operations were found to prefer to engage mid-sized auditing firms probably due to the mid-sized auditing firms' capacity to provide services in foreign locations through their international affiliates.

With regard to auditor-supply factors, we found no significant relationships between the likelihood of engaging a mid-sized auditing firm and whether the client had an internal control weakness or whether the previous auditor resigned. Similarly, clients with a busy-season fiscal year ends were no more or less likely to engage a midsized auditing firm. These results suggest that internal control weaknesses, previous auditor resignations and busyseason fiscal year ends may not dissuade mid-sized auditing firms from accepting these types of companies as audit clients.

Mid-sized firms were found to be more likely to associate with clients from whom they can earn higher revenue. Clients using their external auditors for non-audit services are more likely to hire a mid-sized auditing firm. Similarly, clients who are willing to pay higher audit fees (as a percentage of assets) are more likely to select a midsized auditing firm rather than a small auditing firm. These results suggest that mid-sized auditing firms are more willing to associate with clients from whom they can earn more revenue.

Finally, the results for financial risk are mixed. Going concern opinions were not significantly related to the likelihood of engaging a mid-sized auditor, while financial leverage was negatively related to alignment with a midsized auditor. The non-significant result for the going concern opinion might reflect the protection against potential legal liability losses that a going concern opinion provides should the client financially fail.

The financial leverage results indicate that clients with higher financial leverage are less likely to engage a mid-sized auditing firm as their successor auditor. The client-demand perspective suggests that clients with higher leverage would prefer a mid-sized firm to allay concerns from banks and other credit providers about the credibility of the potential debtor's financial statements. Alternatively, from the auditor-supply perspective, auditors perceive clients with higher financial leverage to be of higher risk to the auditors and thus are less likely to accept these riskier clients. Our empirical results support the auditor-supply effect of auditors wishing to avoid higher risk clients rather than the client-demand effect of clients being more likely to seek out mid-sized auditing firms when they have a higher degree of financial leverage. 
Overall, our results are consistent with auditor-client alignment being associated with both client-demand and auditor-supply factors. Clients with a greater need for a mid-sized auditor were more likely to engage such an auditor. These mid-sized auditors were more likely to accept clients from whom they could earn higher fees. Results for whether mid-sized auditors would avoid financially riskier clients were mixed, with mid-sized auditors being less willing to accept clients with higher financial leverage, but showing no disinclination to accept clients with going concern opinions.

\section{LIMITATIONS}

The research methods used in this study are subject to several limitations. First, we broadly classify the characteristics of clients switching auditors into two categories of client-demand characteristics and auditor-supply characteristics. While we generally examine most of the factors in the literature related to auditor change, this classification may be argued as arbitrary, and some factors, such as company size, sales, and leverage, may belong to both categories. Second, there may be variables that could influence whether a former Big 4 client engaged a midsized or small firm that we do not include in our model. These omitted variables can potentially make our results unfairly reflect how the client-demand and auditor-supply factors affect the successor auditor choice. Third, we use dummy variables to measure some of our constructs, such as foreign operations and non-audit fees. This choice was made based on data limitations and because the majority of clients in our sample had no non-audit fees or foreign operations, which resulted in a skewed distribution.

\section{SUMMARY AND IMPLICATIONS}

We study mid-sized auditing firm client selectivity based on auditor-client realignment in the wake of the Sarbanes-Oxley Act of 2002. Mid-sized auditing firms have a more prominent role in the post-SOX audit markets (e.g. GAO, 2008; Boone et al. 2010; Cullinan et al., 2011). We examined a sample of firms switching from a Big 4 to a mid-sized or smaller auditing firm. We examine factors relating to why clients may wish to select a certain type of auditing firm (i.e., client-demand) and reasons why auditors would be willing to associate with certain clients (i.e., auditor-supply factors).

Consistent with client-demand factors, we find that clients were more likely to engage mid-sized auditors when these clients are larger, have more sales (relative to assets), and have foreign operations. From an auditorsupply perspective, we find that clients are more likely to engage a mid-sized auditing firm when the clients are willing to pay higher audit fees and to use their auditors for non-audit services. Mid-sized auditing firms do not appear to shy away from clients with internal control deficiencies or from which the previous auditor resigned.

Finally, we find mixed evidence regarding whether mid-sized auditing firms are less likely to take on financially riskier clients. Going concerns opinions were not significantly associated with the client's ability to engage a mid-sized auditor (in our multivariate model). However, mid-sized auditing firms were less willing to accept clients with higher financial leverage. Note that from a client-demand perspective, higher financial leverage clients are expected to prefer a mid-sized firm over a small firm due to the potentially positive implication for cost of capital. However, from an auditor-supply perspective, auditor may prefer not to be associated with higher financial risk clients because these clients may be more likely to fail, which could result in reputational and/or legal liability losses for the auditor. Our results may indicate that auditor-supply perspective is stronger than the clientdemand perspective, suggesting that mid-sized auditing firms have the ability to be more selective in their choice of clients.

\section{AUTHOR INFORMATION}

Charlie Cullinan is a professor of accounting at Bryant University. He received his PhD from the University of Kentucky in 1991. His current research interests include corporate governance, audit markets and accounting and auditing issues of mutual funds. He has published in Auditing: A Journal of Practice and Theory, Journal of Accounting and Public Policy, Issues in Accounting Education, Critical Perspectives on Accounting and other journals. E-mail: cullinan@ bryant.edu (Corresponding author) 
Hui Du is an associate professor of accounting at the University of Houston - Clear Lake. She currently serves as an associate editor for Journal of Information Systems. Hui Du received her Ph. D. degree from Rutgers University in 2002. Her research interests include accounting information systems, financial accounting, and auditing. She has published in Journal of Accounting and Public Policy, International Journal of Auditing, Journal of Accountancy, and The CPA Journal. E-mail: duhui1@uhcl.edu

\section{REFERENCES}

1. Albring, S. M., Elder, R. J., and Zhou, J. (2007), "IPO underpricing and audit quality differentiation with non-big 5 firms", International Journal of Auditing, Vol. 11, pp.115-131.

2. Basioudis, I. G. and Francis, J. (November 2007), "Big 4 Audit fee premiums for national and office-level industry leadership in the United Kingdom", Auditing: A Journal of Practice and Theory, Vol. 26 No. 2, pp.143-166.

3. Beatty, R. P. (1989), "Auditor reputation and the pricing of initial public offerings", The Accounting Review, Vol. 64, pp. 693-709.

4. Bédard, J., Coulombe, D. and Courteau, L, (2000), "Demand and supply of auditing in IPOs: An empirical analysis of the Québec market", International Journal of Auditing, Vol. 4, pp. 227-245.

5. Boone, J. P., Khurana, I. K., and Raman, K. K. (2010), "Do the big 4 and second tier firms provide audits of similar quality?", Journal of Accounting and Public Policy.

6. Broye, G. and Weill, L. (2008), "Does leverage influence auditor choice? A cross-country analysis", Applied Financial Economics, Vol. 18, pp. 715-731.

7. Chan, K. C., B. Farrell, P. Healey and P. Lee, (2011) "Firm performance following auditor changes for audit fee savings", Journal of Business and Economic Research, Vol. 9, No. 10, pp. 17-26.

8. Chaney, P. K. Jeter, D. C., and Shuvakumar, L. (2004), "Self-selection of auditors and audit pricing in private firms", The Accounting Review, Vol. 79, No. 1, pp. 51-72.

9. Cullinan, C. P. and Du, H. (2010), "Big 4, "Next 4", and smaller accounting firms: Resignations v. dismissals and the outcome of the auditor change process", The Journal of American Academy of Business, Cambridge, Vol. 16, No. 2, pp. 56-64.

10. Cullinan, C., Du, H. and Zheng, X. (2011), "Has the post-SOX decrease in audit market concentration been costly for shareholders?", working paper, Bryant University, Smithfield, RI.

11. de Mello e Sourza, C. (2004), "Accounting quality vs. auditor choice in a weak regulatory environment with strong Tax-to-GAAP conformity", working paper, Seattle University, Seattle, WA.

12. Dey, R. M. (2010), "The effect of client industry structure on client preference for privacy and auditor concentration”, Managerial Auditing Journal, Vol. 25, No. 4, pp. 361-376.

13. Ebrahim, A. (2010), "Audit fee premium and auditor change: the effect of Sarbanes-Oxley Act", Managerial Auditing Journal, Vo. 25, No. 2, pp. 102-121.

14. Ettredge, M. C. Li, and Scholz, S. (2007), "Audit fees and auditor dismissals in the Sarbanes-Oxley era", Auditing: A Journal of Practice and Theory, Vol. 21, No. 4, pp 371-386.

15. Firth, M. and Smith, A. (1992), "Selection of auditor firms by companies in the new issue market", Applied Economics, Vol. 24, pp. 247-255.

16. Francis, J. R., Maydew, E. and Sparks, H. (1999), "The role of Big 6 auditors in the credible reporting of accruals", Auditing: A Journal of Practice \& Theory, Vol. 18, pp. 17-34.

17. Fuerman, R.D. and Kraten, M. (2009), "Intra-non-Big 4 auditor quality", working paper, Suffolk University, Boston, MA.

18. Geiger, M. A., and Rama, D. V. (2006), "Audit firm size and going concern reporting accuracy" Accounting Horizons, Vol. 20, No. 1, pp. 1-17.

19. Government Accountability Office (GAO) (2008), "Audits of Public Companies: Continued Concentration in Audit Market for Large Public Companies Does Not Call for Immediate Action Washington: GAO”, available at: http://www.gao.gov/products/GAO-08-163

20. Hay, D. and Davis, D. (2002), "The voluntary choice of an auditor of any level of quality", working paper, The University of Auckland, Auckland, New Zealand.

21. Hogan, C. E. and Martin, R. D. (2009), "Risk shifts in the market for audits: An examination of changes in risk for "second tier" audit firms", Auditing: A Journal of Practice \& Theory, Vol. 28, No. 2, pp. 93-118. 
22. Knechell, W. R., Niemi, L. and Sundgren, S. (2008), "Determinants of auditor choice: Evidence from a small client market", International Journal of Auditing, Vol. 12, pp. 65-88.

23. Krishnan, G V., Park, M. S. and Vijayakumar, J. (2008), "Does the flight of clients from the Big 4 to second tier firms indicate a lower audit quality?", SSRN: 1201782.

24. Landsman, W. R., Nelson, K. K., and Rountree, B. R. (2009), "Auditor switches in the pre- and post-Enron eras: Risk or realignment?", The Accounting Review, Vol. 84, No. 2, pp. 531-558.

25. Lawrence A., Minutti-Meza, M. and Zhang, P. (2011), "Can Big 4 versus non-Big 4 differences in auditor quality proxies be attributed to client characteristics?”, The Accounting Review, Vol. 86, No. 1, pp. 259286.

26. Tate, S. L. (2007), "Auditor change and auditor choice in nonprofit organizations", Auditing: A Journal of Practice and Theory, Vol. 26, No. 1, pp. 47-70. 


\section{NOTES}

